\author{
Marcin Kępiński \\ Uniwersytet Łódzki \\ Instytut Etnologii i Antropologii Kulturowej
}

\title{
Etos chłopski i ludzie pracy Nauczyciele z awansu społecznego o pracy w badaniach nad pamięcią Polski Ludowej 2009-2012
}

Świat wokół nas się zmienił, zmieniła się także etnologia/antropologia. Kultura ludowa i lud, wieś, jej tradycje, religijność, obrzędy i rytuały, którymi niegdyś zajmowała się etnografia, zaginęły, uległy zapomnieniu i przekształceniom. Współczesna antropologia zajmuje się zaś zupełnie innymi sprawami, w tym samą sobą ${ }^{1}$. Nieodwracalnym zmianom uległa również wiejska społeczność oraz ważna jej część - tradycyjny chłopski etos, stosunek do ziemi i pracy.

Mój dziadek, Adam Kępiński, oraz moja babcia, Marianna Zając, byli reprezentantami ostatniego pokolenia polskiej wsi, zachowującego pewne niezmienione elementy tradycyjnego etosu chłopskiego. Rodzice mojego ojca, profesora Mariana Kępińskiego, posiadali średnie gospodarstwo rolne we wsi Kamionka, położonej pomiędzy Chełmem a Lublinem². Było to typowe gospodarstwo rodzinne, w którym żyły i pracowały trzy pokolenia, blisko ze sobą związane. Bywałem jako dziecko w domu dziadków regularnie, w okresie wakacji letnich i zimowych, w czasie świąt wielkanocnych i Bożego Narodzenia, siewu, żniw i wykopków. Praca zawsze była treścią ich życia, a właściwie można powiedzieć, że wypełniała je bez reszty. Odkąd tylko pamiętam, ciężka praca od świtu do nocy była codziennym udziałem dziadka i babci. Wolna od niej była tylko niedziela, ale nawet wtedy dziadkowie wstawali równie wcześnie, jak co dzień.

Praca obejmowała zwyczajne chłopskie czynności, związane z ziemią, zwierzętami i gospodarskim obrządkiem, do których potrzeba było siły, umiejętności, cierpliwości, systematyczności oraz zaangażowania. Większość obowiązków wymagających dużej siły, praca w polu i zagrodzie, drobne i większe naprawy, zgodnie $\mathrm{z}$ tradycyjnym podziałem ról w chłopskiej rodzinie, przypadały dziadkowi.

1 Zob. m.in.: J. Barański, Etnologia w erze postludowej. Dalsze eseje antyperyferyjne, Kraków 2017; M. Brocki, Antropologia społeczna i kulturowa w przestrzeni publicznej. Problemy, dylematy, kontrowersje, Kraków 2013; O czym dziś opowiada antropologiczna opowieść? Z prof. Wojciechem Józefem Bursztq rozmawia prof. Agnieszka Ogonowska, „Annales Universitatis Paedagogicae Cracoviensis. Studia de Cultura” V (2013), http://studiadecultura.up.krakow.pl/article/view/1489/1286 [dostęp: 31 I 2019].

2 O historii rodziny ojca, profesora Mariana Kępińskiego, jego malarstwie oraz wsi Kamionka pisałem kilkakrotnie w „Zeszytach Wiejskich” (XII/2007, XV/2010, XXI/2015, XXII/2016). 
W wolnych od naglących obowiązków chwilach, a nie było ich wiele, dziadek Adam lubił zajmować się stolarką w warsztacie, który sam zbudował. Nie był religijny, za to czytywał Pismo Święte, wyciągając z niego swoje własne wnioski. Stanowił typ wiejskiego samouka. A choć ukończył przed wojną tylko szkołę powszechną, lubił czytać gazety i książki („Chłopów” Reymonta znał na pamięć). Miał na to czas późną jesienią i zimą, kiedy gospodarka toczyła się leniwym rytmem, a ziemia odpoczywała. Pochodził z ubogiej rodziny i zanim ożenił się z babcią, córką bogatego chłopa, w młodości pracował jako parobek. Przedwojenny chłopski los i bieda nauczyły go oszczędności i zaradności, a zarazem uczyniły twardym, rzeczowym człowiekiem. W czasie drugiej wojny światowej dziadek Adam był członkiem wiejskiego oddziału Armii Krajowej (ps. Olek), brał udział w akcjach zdobywania broni i pieniędzy od niemieckich okupantów. Jednak nie lubił o tym mówić; w ogóle nie był gadatliwy i nigdy niczym się nie chwalił. Uważał się za Polaka i patriotę, ale przede wszystkim za chłopa, z czego był prawdziwie dumny. Ponieważ przed wojną zaznał w życiu ubóstwa, doceniał awans społeczny mieszkańców wsi, jaki stał się udziałem jego pokolenia po 1945 roku. Choć niechętny komunizmowi - w latach stalinowskich zabrano mu siłą krowę do spółdzielni - szanował władzę ludową za inwestycje na wsi, elektryfikację, powszechne i bezpłatne szkolnictwo, opiekę zdrowotną, kredyty inwestycyjne i mechanizację rolnictwa. Do końca życia był jak najlepszego zdania o Edwardzie Gierku, którego określał jako prawdziwego gospodarza Polski, a w dodatku zainteresowanego, jak nikt wcześniej, rozwojem rolnictwa w kraju. Sam oszczędny, wręcz skąpy i zadowalający się konsumpcyjnym minimum, dziadek Kępiński chętnie inwestował w gospodarstwo i budynki gospodarcze. Kupował maszyny rolnicze i ziemię. Pozwolił sobie nawet na luksus i zrealizował marzenie z młodości - kupił motocykl. Prawdziwego potwora, ogromne radzieckie monstrum marki IŻ, ze specjalnym, mocnym silnikiem i zawieszeniem, przeznaczonym na bezdroża ZSRR. Choć skąpy, dla wnuków nigdy nie żałował drobnych pieniędzy, cukierków czy prezentów. Koniecznie musiały być praktyczne i dobrej jakości, jak na przykład scyzoryk marki Gerlach czy radziecki zegarek Poljot. Od niego dostałem swój pierwszy rower, na którym nauczył mnie jeździć i czasami wyprawialiśmy się wspólnie do pobliskiego miasteczka Siedliszcze.

Życiowe doświadczenie, refleksyjna natura, obserwacja przyrody, bliższego i dalszego otoczenia oraz lektury i samodzielnie zdobyta wiedza pozwoliły dziadkowi na stworzenie swoistej życiowej filozofii. Jej częścią były elementy tradycyjnego etosu chłopskiego - wartości: praca, ziemia, sprawiedliwość oraz życie w zgodzie z przyrodą. Zarówno dziadek, jak i babcia czuli się jeszcze częścią większej całości - świata natury, z którą należało żyć w zgodzie. Ziemia była dla dziadka czymś najważniejszym. Traktował ją jak świętość, nigdy by jej nie sprzedał ani nie wydzierżawił. Gospodarka, dom, pola, łąki i pobliski las były jego światem. Nie chciał i nie lubił ich opuszczać, dlatego prawie nigdy nie wyjeżdżał. Mawiał, że ziemię trzeba szanować i odpowiednio traktować, a wtedy odwdzięczy się obfitymi plonami. 
Dziadek Adam nie mógł spokojnie patrzeć na marnotrawstwo i partactwo, jakie jego zdaniem odbywało się w pobliskim Państwowym Gospodarstwie Rolnym. Uważał, że każde pole powinno mieć jednego gospodarza, wiedzącego najlepiej, jak o ziemię zadbać. W jego gospodarstwie panował wzorowy porządek. Jego zdaniem najważniejszym i najlepszym zawodem na świecie był ten, który on sam wykonywał, czyli zawód rolnika. Była to jedyna godna uczciwego człowieka praca, w dodatku dająca chleb innym. Dziadek nie lubił sąsiadów, którzy nie chcieli lub nie potrafili gospodarzyć jak należy - w pocie czoła, rzetelnie. Znał dobrze historię Polski i sądził, że chłopi zawsze byli niedocenianą, a jednocześnie najbardziej wartościową częścią polskiego społeczeństwa, to na nich bowiem spoczywał obowiązek największy i najważniejszy - wyżywienie kraju. Szanował tych wszystkich, którzy - jak chłopi i robotnicy - utrzymywali się z pracy własnych rąk. Pracować powinien każdy, a wyznaczoną pracę należy wykonywać jak najlepiej. Nauczycieli tolerował, sądził bowiem, że są potrzebni, zwłaszcza ze względu na praktyczną stronę wiedzy, jaką przekazują. Dla urzędników, dyrektora PGR, sekretarza organizacji partyjnej miał co najwyżej uśmiech politowania oraz spore pokłady nieufności. Podobnie jak dla mieszkańców miast, którzy jego zdaniem nie znali prawdziwego życia, w łączności z ziemią i przyrodą. Kilka razy, może dwa, odwiedził nas w Łodzi, ale pośród fabrycznych murów i bloków bardzo źle się czuł, jakby brakowało mu powietrza. Nie rozumiał miejskiego życia. $\mathrm{Z}$ tego powodu jego wizyty nie trwały długo. Dziadek wolał nas gościć w swoim przestronnym domu, położonym pośród pięknych, rozległych pól, w pobliżu starego lasu, z sadem i pasieką.

Po latach zrozumiałem surowość dziadka, jego oszczędność w słowach, wypytywanie o świadectwa (nauka w końcu była moją pracą jako ucznia), a także to, że nie poświęcał nam, swoim wnukom, zbyt wiele czasu. Po prostu go nie miał. Zapamiętałem, że nigdy się nie skarżył ani nie narzekał, mimo że był coraz starszy i ubywało mu sił do pracy. Podziwiałem jego wytrwałość, hart i pogodę ducha. Zrozumiałem także piękno jego prostej, chłopskiej filozofii życia, o której tak rzadko mówił. Niestety, przeminęła wraz z pokoleniem dziadka. Nostalgia sprawia, że mityzuję zarówno jego postać, jak i ulubione miejsce dzieciństwa - polską wieś. Z pewnością nie były idealne, ale jednak bliskie ideałowi.

O nieuchronnym przemijaniu chłopskiego etosu czytamy w wywiadzie z Rochem Sulimą: „(...) na prowincji dogorywa coś, co nazwać można etosem chłopskim, etosem szlacheckim. Załamał się odwieczny rytm życia prowincji, jednorodny styl bytowania, na co zwracał kiedyś uwagę Stanisław Vincenz. Dziś wszystko się wymieszało, jest chaos. Chaos w świecie wartości, chaos w stylach życia. Widzę, że ludzie nie potrafią odorać skiby od miedzy, co było za moich młodych lat nie do pomyślenia. Kultura rzeczy, kultura przedmiotów, tworzących kiedyś względnie jednorodną całość, uległa głębokiej dysharmonii. Niski jest stan tego, co nazwałbym kulturą bytu. Te podstawy życia, które wyznaczało uprawianie ziemi, a więc wszystkie obowiązki wobec pola, wobec Boga, wobec Kosmosu, wobec innych ludzi - zniknęły (...). A przecież nie tak dawno ludzie wstawali ze świtem, czy mieli coś do roboty, czy nie, Bóg wzywał, bo słońce już na niebie. 
I właśnie ten etos umarł. Ale my tworzymy, moim zdaniem, pożyteczną kulturową fikcję, że gdzieś indziej, poza metropolią, istnieje jakiś świat uładzony, świat przedustawnych wartości, i że to będzie dla nas jakieś miejsce ocalenia (...)”3. Choć nie wszyscy współcześni badacze wsi zgadzają się ze stwierdzeniem, że chłopski etos zupełnie się skończył (na przykład: Tadeusz Chrobak, Józef Styk, Stanisław Siekierski, Łukasz Hajduk), to jednak trzeba przyznać, że zanikł on w swej tradycyjnej postaci, ulegając daleko idącym zmianom. Być może gdzieś jednak przetrwały niektóre jego elementy. Choć nie mamy kultury ludowej ani folkloru, a jedynie różne nowoczesne formy kultury typu ludowego i folkloryzmu, to jednak dzięki nim możemy mieć nadzieję, że ważna część naszego duchowego dziedzictwa nie zniknie we wszechobecnym zalewie kultury popularnej, o którym wspomina w cytowanym wywiadzie Roch Sulima.

Sądzę, że niektóre z elementów składowych tradycyjnego etosu chłopskiego można odnaleźć w zebranych przez mnie, w czasie kilkuletnich badań nad pamięcią Polski Ludowej, narracjach grupy łódzkich nauczycieli. Moje spostrzeżenie dotyczy tych spośród badanych, którzy wywodzą się z rodzin wiejskich. Zawód nauczyciela wykonywali dzięki możliwości awansu społecznego, stworzonego przez władze. W przeprowadzonych wywiadach wyraźnie widać wpływ zinternalizowanych w kręgach rodzinnych wartości na ich biografię oraz stosunek do wykonywanej pracy nauczyciela ${ }^{4}$.

Temat etosu chłopskiego i związanej z nim centralnej wartości pracy oraz ich zmiany zajmowały wielu badaczy ${ }^{5}$. W swej klasycznym opracowaniu Anna Zadrożyńska opisywała poglądy na wartość pracy, porównując tradycyjny model pracy rolnika, model przejściowy (praca Państwowych Gospodarstw Rolnych) oraz model miejski. Barbara Fedyszak-Radziejowska wymieniła cztery modele etosu pracy rolników: tradycyjny, agrarystyczny, miejsko-marksistowski i etos rolnika-producenta.

Wiemy, że w tradycyjnej kulturze chłopskiej praca „stanowiła wartość centralną, autoteliczną. Wokół pracy zbudowany był tradycyjny system wartości, praca wypełniała życie całej rodziny chłopskiej. Kontekst emocjonalny pracy, szczególnie fizycznej, był zawsze pozytywny. Zajęcia nie będące pracą zwano próżnowaniem i silnie potępiano. Praca stanowiła nie tylko źródło prestiżu i zamożności, lecz także cel sam w sobie, treść codziennego życia. Podobnie ważną

3 Ludzie potrzebujq inności. Rozmowa z prof. Rochem Sulimq, „Przegląd” nr 34/2009, https://www.tygodnikprzeglad.pl/ludzie-potrzebuja-innosci/ [dostęp: 31 I 2019].

4 Artykuł wykorzystuje fragmenty wywiadów cytowanych w mojej wcześniejszej książce: Pomiędzy pamięciq autobiograficzna a zbiorowa. Polska Ludowa i stan wojenny w narracjach łódzkich nauczycieli, Łódź 2016. Z racji ograniczonej objętości nie zajmowałem się w niej opisywaną w artykule problematyką etosu chłopskiego i pracy, obecną w narracjach moich informatorów. Również w książce piszę szeroko o prowadzonych badaniach i ich metodologii, tu więc pominę ten temat.

5 Zob. m.in.: A. Zadrożyńska, Homo faber, homo ludens. Etnologiczny szkic o pracy w kulturach tradycyjnej i współczesnej, Warszawa 1983; M. Halamska, H. Lamarche, M.C. Maurel, Rolnictwo rodzinne w transformacji postkomunistyczej. Anatomia zmiany, Warszawa 2003; B. Fedyszak-Radziejowska, Etos pracy rolnika. Modele społeczne a rzeczywistość, Warszawa 1992. 
rolę pełniła ziemia, czynnik prestiżotwórczy, cel wielu chłopskich działań i zabiegów”6. Taki układ tradycyjnych chłopskich wartości nazywano agrocentrycznym.

Przypomnijmy, że choć etos w naukach o kulturze jest rozumiany na wiele sposobów, to jednak podkreśla się w nich znaczenie świata wartości oraz ich wpływ na życie i postępowanie wspólnoty. W etnografii określa się etos jako „styl życia obyczajowo-moralny”, powiązany z normami, sankcjami i obyczajami. Etos stanowi również układ idei, dominujących w danej grupie i kulturze, integrujących ją i zapewniających jej wewnętrzną harmonię. Termin ten upowszechnił się głównie w znaczeniu „charakterystycznego dla danej grupy społecznej zespołu reguł obyczajowo-moralnych lub/i faktycznie obowiązującego w danej grupie społecznej typu moralności; całościowego wzoru kultury danej społeczności lub stylu życia obowiązującego w danej grupie społecznej (...)"” . Co do etosu chłopskiego, można w nim wyróżnić kilka konstytutywnych elementów.

Jednym z nich, najważniejszym, jest właśnie praca, bardzo silnie łącząca się z ziemią. W tradycyjnej chłopskiej kulturze „dobro jakim jest ziemia »domaga się« od człowieka pracy. Przy czym praca upoważnia jednostkę tylko do korzystania z ziemi, a nie do jej przywłaszczania na zasadzie wyłączności. Niezależność bytowa ziemi sprawia, że człowiek uprawniony jest do korzystania z niej proporcjonalnie do włożonej pracy. (...) Ta symetryczność związku między ziemią i człowiekiem zachodzi przede wszystkim w pracy rolnika"8. przypomnieć, że „wartości etosu chłopskiego istnieją jako nadbudowane przede wszystkim nad relacjami zachodzącymi między ziemią a chłopem rolnikiem. Wielopostaciowe związki chłopa z ziemią są zasadniczym czynnikiem kreatyw-

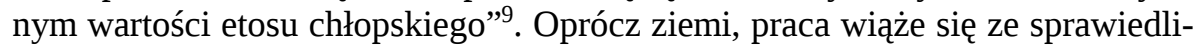
wością, kolejną fundamentalną dla tego etosu wartością: „podstawą sprawiedliwości ekonomicznej jest praca, traktowana jako wyróżnik warstwy chłopskiej i wartość fundamentalna etosu chłopskiego"10. Bardzo podobne stwierdzenia znajdziemy w opracowaniu Stanisława Siekierskiego. dotyczącym etosu chłopskiego w świetle pamiętników prowadzonych przez chłopów od początków ich piśmiennictwa aż po okres zmiany ustrojowej po 1989 roku: „dla chłopów, pozostających na wsi, ziemia jest wartością podstawową, ona nie tylko stanowi warunek egzystencji, ale nadaje sens i wartość ich życiu, określa chłopski los”11.

Ziemia nie była tylko biologiczną podstawą życia chłopskiej rodziny, ale mikrokosmosem chłopa, zawierającym w sobie miejsce, rodzinę, przestrzeń. W tradycyjnych chłopskich społecznościach ziemia była wartością autoteliczną, silnie łączoną z czynnikami gospodarczymi i ekonomicznymi oraz pracą: ,jedną z istotnych cech chłopstwa, niezależnie od miejsca i czasu, jest silny związek

$6 \quad$ B. Fedyszak-Radziejowska, dz. cyt., s. 33.

7 Zob.: J. Grad, Etos, [w:] Słownik etnologiczny. Terminy ogólne, red. Z. Staszczak, Warszawa-Poznań 1987, s. 111-113.

8 T. Chrobak, Etos chłopski w programach stronnictw ludowych, Rzeszów 1992, s. 41.

9 T. Chrobak, dz. cyt., s. 119.

10 Tamże, s. 122.

11 S. Siekierski, Etos chłopski w świetle pamiętników, Kraków 1992, s. 69. 
z ziemią. Wynika to nie tylko z jej niezbędności jako środka produkcji, ale również z tożsamości miejsca zamieszkania, z miejscem rodziny chłopskiej. Występuje silne sprzężenie przestrzenne, funkcjonalne i rzeczowe gospodarstwa rolnego $\mathrm{z}$ gospodarstwem domowym. Wspólnie tworzą przestrzenne ramy egzystencji. Rodzina, gospodarstwo rolne oraz gospodarstwo domowe, połączone czynnikiem pracy stanowią podstawową trójjedność chłopskiego systemu wartości”12.

Stosunek do pracy, traktowanej jako moralny obowiązek człowieka, był charakterystyczny dla tradycyjnego etosu chłopskiego. Przez pracę we własnym gospodarstwie chłop uczestniczył w działalności sił przyrody, a wszystko co posiadały chłopskie rodziny, zawdzięczały wyłącznie ciężkiej pracy. Świat chłopski miał „charakter fizyczny, konkretny i pragmatyczny. Dlatego mało była dla niego zrozumiała praca umysłowa, a szczególnie typu biurokratycznego i organizatorskiego. Byłą dla niego obca, niezrozumiała, dlatego traktowana nieufnie"13.

Najważniejszą cechą charakteru chłopa polskiego była pracowitość: „Praca oznaczała nie tylko sposób zaspokojenia potrzeb, lecz była rodzajem mistycznego zespolenia ze światem przyrody oraz stanowiła udział w stwórczej mocy Bożej jako obowiązek religijny. Poczucie obowiązku pracy było najsilniejszą normą moralną. (...) miała w sobie coś z charakteru sakralnego. Uległ on zachwianiu poprzez stosowanie doskonalszych narzędzi, a następnie w wyniku mechanizacji. Pracowitość zatem była traktowana jako wartość sama dla siebie, bez której nie mogło być mowy o dobrym gospodarowaniu. Stanowiła ona podstawowy kapitał, który - obok ziemi - był najważniejszą cechą chłopa"14. Pracowitość oznaczała właściwie brak czasu wolnego w dzisiejszym rozumieniu tego słowa oraz pełną dyspozycyjność wobec potrzeb gospodarstwa. Jedną z cech charakterystycznych tradycyjnych społeczności wiejskich, na jaką zwracali uwagę etnolodzy, był brak podziału na czas wolny i czas pracy ${ }^{15}$. W tradycyjnym modelu etosu pracy, opisanym przez Annę Zadrożyńską, czas pracy uzupełniano zabawą, nie rozdzielając tych dwóch form ludzkiej aktywności ${ }^{16}$.

Kolejną pożądaną cechą charakteru chłopa byłą oszczędność, połączona z minimalizmem konsumpcyjnym: „Oszczędzano we wszystkich rozumieniach tego pojęcia. Dążono do całkowitego zużycia danej rzeczy (bez reszty), do nieniszczenia, a także do opóźniania zużycia tego, co najlepsze. (...) Oszczędzania pieniędzy poprzez ich odkładanie miało na celu wydatkowanie na cele trwałe (głównie inwestycyjne). Wydatki były dokonywane po długim namyśle, a konsumpcję utrzymywano na poziomie niskiego minimum" ${ }^{17}$. Oszczędzano zarówno sprzęty gospodarstwa domowego, jak i ubrania, maszyny i urządzenia, a nawet pożywienie. Gospodarowano w sposób racjonalny, a oszczędność była tożsama

12 J. Styk, Chłopski świat wartości. Studium socjologiczne, Włocławek 1993, s. 33.

13 Tamże, s. 48.

14 J. Styk, dz. cyt., s. 26-27.

15 Zob.: A. Zadrożyńska, Powtarzać czas poczq̨tku. Część I. O świętowaniu dorocznych świq̨t w Polsce, Warszawa 1985, s. 136-137.

16 Zob. A. Zadrożyńska, Homo faber..., s. 221.

17 J. Styk, dz. cyt., s. 27. 
z gospodarnością. Rozumiano ją jako „wykorzystanie wszystkiego, co gospodarstwo posiadało. Zewnętrzne przejawy polegały na porządku w domu, zagrodzie i polach. Chodziło głównie o funkcjonalność, niezbędną przy szerokim zakresie czynności zawodowych”18. Gospodarność jako cecha dobrego gospodarza powinna była występować razem z pracowitością i oszczędnością. Wtedy taki chłop mógł liczyć na wysoką ocenę społeczną w swojej wspólnocie lokalnej.

Moralne wzorce dotyczące pracy, jako niezbywalnej części chłopskiego etosu, przekazywano $\mathrm{w}$ rodzinie, podczas procesu socjalizacji i wychowania. Miały one charakter rodzinny, dokonywały się poprzez codzienną, wspólną pracę. Celem wychowania było „przygotowanie jednostki do samodzielnego i pełnego uczestnictwa w życiu rodzinnym i lokalnym oraz do prowadzenia gospodarstwa. Wychowywanie odbywało się przede wszystkim przez pracę, świadczoną na rzecz gospodarstwa od najmłodszych lat życia. Dzięki temu następowało wszczepienie najbardziej pożądanej cechy osobowości: pracowitości. (...) Więzi międzypokoleniowe były bardzo silne oraz dawały stałą obecność trzech perspektyw czasowych: przeszłości (dziadkowie), przyszłości (dzieci) oraz teraźniejszości (rodzice). Doświadczeniu praktycznemu towarzyszyło objaśnianie słowne oraz zabiegi korekcyjne" ${ }^{19}$. Dodajmy, że rodzice, choć surowi w ocenach i zachowaniu, byli obdarzeni przez dzieci ogromnym autorytetem. Model takiego wychowania zakładał przekazywanie dzieciom przez rodziców norm moralnych oraz pełne posłuszeństwo: „dobre dziecko było przede wszystkim posłuszne oraz pracowite. Najwięcej uwagi poświęcano tym dzieciom, które były przewidywane na dziedzica gospodarstwa" ${ }^{20}$. Ten rytm pokoleniowej wymiany oraz przekazywania etosu chłopskiego już w okresie dwudziestolecia międzywojennego zakłóciła szkoła przez wprowadzenie powszechnego obowiązku szkolnego ${ }^{21}$.

W tradycyjnych chłopskich rodzinach dziecko „wchodziło w cykl produkcyjny w wieku pięciu, sześciu lat, a w proces wychowywania młodszego rodzeństwa znacznie wcześniej. Przygotowanie do życia zawodowego rozpoczynało się praktycznie od momentu własnej, biologicznej samodzielności. Wychowywało dziecko rodzeństwo, stopniowo uczyło się hodowli gęsi, bydła, koni, w większych gospodarstwach drobiu i świń. Już od najmłodszych lat uczestniczyło także jako pomoc w pracach polowych”22. Dodajmy, że prawie zawsze była to praca wymagająca samodzielności, zaangażowania i sporego nakładu siły. Szkoły okazały się prawdziwym szokiem wychowawczym dla wiejskiej społeczności: „naruszyły one jednorodny system wychowawczy. Uczyły dzieci wiedzy prawie całkowicie zbędnej, po drugie - wytrącały z cyklu produkcyjnego ważne ogniwo: pastuchów i pomocników (...)”23. Jednak dopiero po drugiej wojnie światowej awans dzieci chłopskich do grupy inteligencji stał się dużo łatwiejszy. Umożliwiły to władze Polski Ludowej, zapewniając dzieciom z rodzin chłopskich i robotniczych szereg

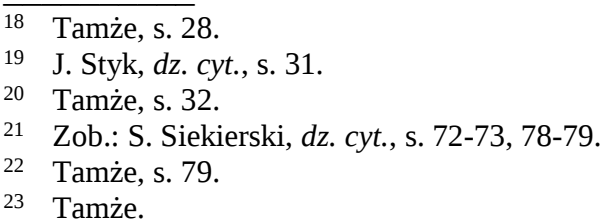


ułatwień i opiekę socjalną w trakcie zdobywania wykształcenia średniego i wyższego ${ }^{24}$.

Wracając do konstatacji o nieuchronnym przemijaniu etosu chłopskiego i związanej z nim wartości pracy, okazało się, że pewne jego pozostałości da się odnaleźć w zebranych przeze mnie narracjach łódzkich nauczycieli wywodzących się z rodzin chłopskich. Wszystkie one są do siebie podobne, zarówno jeśli chodzi o typ używanych argumentów, jak i treść wspomnień z dzieciństwa i pracy zawodowej w szkole. Łączy je również rzetelny stosunek do pracy, przekazany nauczycielom przez rodziców. Nauczyciele pochodzący z wielodzietnych rodzin chłopskich (oraz robotniczych) podkreślają biedę, jaka panowała w ich domu. Jednak zarówno sam dom, jak i rodziców wspominają ciepło, z nostalgią. Ich rodzice byli przedstawicielami pokolenia, które szanowało ziemię, pracę, było prawdomówne i oszczędne. Te wartości przekazało swym następcom - wykształconym dzieciom. Co ciekawe, rodzice nie sprzeciwiali się aspiracjom zawodowym przyszłych pedagogów, a wręcz przeciwnie - popierali ich dążenia do awansu społecznego. Ze swych dzieci byli dumni, widząc w ich migracji do miast (ale i powrotach do wiejskiej szkoły) wielką szansę, którą należało wykorzystać jak najlepiej.

Elżbieta M., urodzona w 1936 roku we wsi Chabielice, nauczycielka techniki i plastyki, mówiąc o swoim domu, podkreśla panującą w nim biedę, brak podstawowych rzeczy, ogólnodostępnych w czasach współczesnych (ciepłe ubrania, pralka) i konieczność ciągłej pracy - pomagania rodzicom. Dom był jednak, dzięki matce informatorki, pełen rodzinnego ciepła: „Mój rodzinny dom. Nas było czworo, wielodzietna rodzina. Moi rodzice na Przestrzennej mieli gospodarstwo rolne. My, dzieci, musiałyśmy pomagać, prace w polu. Często było tak, że trzeba było, przychodziłam ze szkoły: »Tam jest zupa, proszę zjeść, idziemy ziemniaki kopać«. We wrześniu kopać, taką dziabką. Potem, na wiosnę, buraki pielić, żniwa, zboże zbierać, bo nie było kombajnu, nie było niczego, kosą tata kosił z wujkiem, a my z siostrą i mama, myśmy zbierali. Ale mimo to wspominam swój dom bardzo ciepło i było biednie, dziecko po dziecku nosiło to, co przestało nosić, bo wyrosło. Ja miałam pierwsze palto, palto takie cieplejsze, to ja miałam dopiero, jak byłam w maturalnej klasie, to ja miałam dziewiętnaście lat. Bo tak, to chodziłam w podgumowanym płaszczu i w żakiecie starym babci. I w tym chodziłam. I takie kalosze były, pamiętam, i w tym się chodziło. Bo matkę nie było stać, żeby cokolwiek kupić, jak miała czworo dzieci. Nawet na zeszyty. Proszę pani, ja dostawałam sto trzydzieści złotych stypendium, ze względu na dużą rodzinę i ja robiłam na drutach rękawiczki, tutaj sąsiadki dzieciom, obszywałam chusteczki (...), to sobie zarobiłam siedemdziesiąt złotych. I za to sobie kupiłam to płaciłam bilet na tramwaj. Więc to były ciężkie czasy dla dzieci, dla nas, ale mimo wszystko ja je tak ciepło i serdecznie wspominam. I wie pani, mama pralki nie miała, mama

24 Oprócz powszechnie znanych faktów historycznych, temat awansu społecznego porusza analiza pamiętników chłopskich dokonana przez S. Siekierskiego (dz. cyt., s. 78-81, 116-117), a także inne, podobne opracowania, np. klasyczne, wielotomowe Młode pokolenie wsi Polski Ludowej pod redakcją J. Chałasińskiego. 
prała na takiej pralnicy. (...) I wie pani, u nas było czysto” (AIEIAK 10757, s. 2). Rodzinny dom nauczycielki, która należała do wykształconego po wojnie pokolenia dzieci wiejskich, pracującej w szkole dzięki awansowi społecznemu, jest opisywany jako niezwykle biedny, ale szczęśliwy. Przedmioty i ubrania, które dzisiaj są zwyczajne i używane codziennie, w czasach jej dzieciństwa stanowiły niedostępny luksus. Samo miejsce zamieszkania również pozostawało poza obszarem dostatku i obszernej przestrzeni, dostępnej dla każdego domownika. Był to zwyczajny, biedny dom: „Było to dwuizbowe mieszkanie, bo to był dom, i znaczy, jedno takie większe mieszkanie, gdzie się odrabiało lekcje i było łóżko, rodzice tam spali, a my w drugim pomieszczeniu. No, było zawsze czysto, schludnie, mama była gospodarna, zawsze coś tam upiekła. I święta wspominam, były bardzo zawsze, bardzo ciepłe, bardzo takie swojskie, takie kochane. Z tym że naprawdę nie było zabawek, tak jak powiedziałam, u rodziców bawiliśmy się w szkołę albo w sklep” (AIEIAK 10757, s. 2). Dla informatorki nie jest ważny dom jako miejsce, ale ci, którzy wypełniają go uczuciami, swoją obecnością i nadają mu charakter bezpiecznej przystani dla rodziny. Rodzinę spaja matka, przekazująca proste, najzwyklejsze wartości moralne, ucząca dzieci uczciwości, poszanowania pracy oraz siebie nawzajem. Matka zmarła mając 94 lata, dzieci nie chciały nigdzie jej oddawać, do samego końca była w domu, pod ich opieką. Ojciec zmarł dużo wcześniej, ale „mama była z rodziną do ostatniego tchnienia. Także ta rodzina nasza istniała cały czas, a jeszcze muszę wspomnieć, że moja matka, mając osiem lat straciła swoją matkę, a dwanaście ojca. Zostało czworo dzieci na wsi, tam w Chabielicach i te dzieci się same wychowywały. (...) I te dzieci mieszkały w jednej izbie, cała ta czwórka i mama była wielka gospodyni, piekła chleb. Więc proszę sobie to wyobrazić. Więc jak ja, jak mama opowiadała, to ja, to mnie ściskało. I wychowała swoje dzieci dobrze, była bardzo wymagająca, goniła nas do roboty, ale mogę jej tylko za to podziękować, bo wychowane dzieci w pracy... [podkr. - M.K.] Ja uważam, że praca, nie ma myśli o głupotach. (...) Także wie pani co, że ten dom rodzinny ma wielkie oddziaływanie na dzieci. Dziecko może dostać wszystko, ale jeżeli nie ma ciepła, jeżeli nie ma atmosfery rodzinnej, nic nie będzie. To jest to, co teraz się dzieje (...) rodzice gonią nie wiadomo za czym, największy skarb tracą. Tracą swoje dzieci. To jest skarb” (AIEIAK 10757, s. 3).

Mimo panującej w powojennych czasach biedy informatorka wspomina swój rodzinny dom z dużą dozą nostalgii. Choć na wsi nie było wielu potrzebnych, najprostszych rzeczy materialnych, to nie brakowało uczuć, dobra i wzajemnej miłości. W innym miejscu wywiadu opowiada o ojcu, który po dniu spędzonym na ciężkiej pracy w polu, poświęcał swoim dzieciom czas, czytając im wieczorem książkę. Elżbieta M. mówi, że praca była zawsze i pozostanie dla niej najważniejsza. Całe jej życie minęło na pracy w: szkole, domu, ogrodzie, polu. Życiowa zaradność i pracowitość jakich nauczono ją w domu, pomogły w jej dalszym życiu. Dzięki zdobytemu wykształceniu miała możliwość przekazywania młodzieży szkolnej wpojonych w domu zasad moralnych. Uważa pracę za wartość autoteliczną: „Wartości? Na pewno nie materialne, absolutnie nie. Natomiast właśnie te wartości wychowywania tej młodzieży. Dla mnie to było takie istotne, 
nawet mama mówiła: »Ty zawsze o tych dzieciach mówisz«. Dla mnie to było ważne, żeby się coś działo takiego właśnie pozytywnego, zresztą byłam bardzo czynna w szkole. Wszystkie imprezy to były moje pracownie (...) jak trzeba było robić dekoracje, to ja robiłam, bo moje były dekoracje ładne, na różne imprezy, jak to w szkole, wie pani. Także, właśnie bym powiedziała, że rodzinne wartości są dla mnie ważne, powiedzmy właśnie, szanowałam pracę, to jest wartość, to jest wartość bym powiedziała, z tego co pani mówiłam. I tak ja uważam, że zawsze musi być konsekwencja i musi to wszystko być w porządku, dobrze zrobione" (AIEIAK 10757, s. 5). Elżbieta M. podkreśla, że mimo bardzo małej pensji nauczycielskiej, która zaraz po rozpoczęciu pracy w szkole, po ukończeniu liceum pedagogicznego, nie wystarczała jej na porządne buty, zawsze starała się wykonywać obowiązki nauczycielki jak najlepiej. Szczerość i wierność zasadom wpojonym przez matkę trochę przeszkadzała jej w pracy, szczególnie w relacjach z innymi nauczycielami, którzy nie byli do końca uczciwi: „byłam, tak jak mówię, konsekwentna i nawet troszkę za bardzo byłam konsekwentna i co miałam powiedzieć, to powiedziałam (...): »Czy to się tobie podoba, czy nie, to ja mówiłam i koniec. Bo tak się nie powinno zrobić«. A i byłam na przykład bardzo konsekwentna jeśli chodzi o narzędzia, które pożyczali ode mnie z pracowni [koledzy nauczyciele - M.K.]. Musieli mi je oddać, ja zapisywałam do sztuki. A jak sztukę brakowało, to odkupywali. Bo ja bym nie miała nic w pracowni, jakbym tak, każdy by sobie wziął i zapomniał oddać, bo tak zwykle jest” (AIEIAK 10757, s. 5). Uczciwość, pracowitość i prostolinijność to cechy matki tej nauczycielki, które przekazała swej córce. Wedle wyznawanych przez informatorkę zasad, bliskich stosunkowi do pracy i funkcjonowania jednostki w tradycyjnej kulturze chłopskiej, każdy powinien jak najlepiej wykonywać swoją pracę, pozostając na przynależnym mu miejscu pracy: „Niech każdy robi to, co do niego należy, tylko niech zrobi dobrze, starannie i będzie dobrze. Zawsze miałam to zdanie i tak tłumaczyłam dzieciom. (...) To, co mamy robić, to róbmy starannie i dobrze, to drugiemu człowiekowi pomożemy [podkr. - M.K.]. Bo każdy jak zrobi, jak to się mówi: "piekarz piecze« tam ten, taki wierszyk dzieciom się... Tak, pamiętam: »Koszykarz koszyki plecie, każdy pracuje na świecie«” (AIEIAK 10757, s. 12).

Elżbieta M. była przewodniczącą ZNP w swojej szkole, ale nie należała do partii. Z jej opowieści o trudnym, choć szczęśliwym życiu w PRL-u wynika, że w pełni akceptowała zmiany ustrojowe po drugiej wojnie światowej, jakie dokonały się w Polsce. Docenia zwłaszcza możliwość awansu społecznego, jaką socjalistyczny ustrój stwarzał biednym dzieciom z rodzin chłopskich i robotniczych. Ona sama, jak mówi, jest tego najlepszym przykładem. Studia na Wydziale Filozoficzno-Historycznym Uniwersytetu Łódzkiego ze specjalizacją nauczycielską, ukończyła dopiero w wieku czterdziestu trzech lat. Kariera zawodowa, jaka stała się jej udziałem, udała się dzięki ciężkiej pracy, cierpliwości oraz wykorzystaniu możliwości danych jej pokoleniu w Polsce Ludowej. Dlatego też informatorka ma o PRL-u dobrą opinię i wyraża ją w wielu fragmentach swej narracji.

Podobnie o pracy, pracowitości i prawdomówności jako ważnych wartościach, wpojonych w domu rodzinnym, mówi Teodozja W., urodzona 
w 1933 roku, nauczycielka matematyki. Pochodząca ze wsi Leśne Odpadki, położonej w pobliżu Łodzi, informatorka urodziła się i wychowała w wielodzietnej, chłopskiej rodzinie.

Rodzinny dom wspomina bardzo dobrze: „Mianowicie jestem najstarsza z czwórki rodzeństwa. Rodzice bardzo dbali, żebyśmy się uczyli. Ja, prawda, skończyłam ten uniwersytet. Mój ojciec bardzo się chwalił, kiedy byłam studentką i już mniej, kiedy byłam nauczycielką. (...) Moja młodsza siostra, Czesia, skończyła politechnikę. Jest inżynierem chemikiem. Pozostała dwójka nie uczyła się. Moi rodzice uważali, że jeżeli dziecko ma trójki, to już się nie nadaje do wysyłania do szkoły, ale na przykład, z perspektywy widzę, że moja siostra wśród gospodyń wiejskich jest inteligentna, z dowcipem, nie mówiąc o jej sercu. (...) W każdym razie bardzo się szanujemy, rodzice nas wychowali do pracy. U nas nie było tego, że ktoś się uczy, to jest kimś lepszym. Przyjeżdżało się do domu, zakładało spodnie i szło do pracy. Nie umiem tylko krów doić, bo jakoś mamusia nie zdołała nas do tego nakłonić, ale tak to wszystkie prace, łącznie z rozrzucaniem obornika. I ja nie uważam, żeby to było złe” (AIEIAK 11036, s. 1). Czytać i pisać z przedwojennego elementarza oraz podstaw rachunków nauczyli Teodozję W. rodzice, więc mogła po 1945 roku iść do trzeciej klasy szkoły podstawowej. Jej ojciec przed wojną był sołtysem i skończył szkołę rolniczą w Czarnocinie, o czym informatorka z dumą opowiada. Zdobyte umiejętności pozwalały mu na doradzanie sąsiadom w sprawach gospodarstwa i rolnictwa. Ojciec: „był pracowity, bardzo pracowity, kochający dzieci. Nigdy się nie mówiło, że my was tak kochamy, ale to się czuło, a poza tym, z perspektywy lat widzę, że wśród tej zapijaczonej wsi, to ten mój dom był taką oazą. Nie jakiś tam abstynentów, nie... Tylko ja nie pamiętam, żeby w życiu ojciec coś tam przepił, a to się zdarzało" (AIEIAK 11036, s. 2). Nauczycielka matematyki dokonuje oceny postępowania ojca z punktu widzenia minionego czasu i powrotu pamięcią do trudnego, ale szczęśliwego dzieciństwa. Pomoc okazywana ze strony rodziców i chęć wykształcenia dzieci uważanych za uzdolnione, przejawiała się choćby w tym, że ojciec informatorki odwoził ją i jej rodzeństwo do szkoły w Kurowicach, często pokonując tę samą drogę kilka razy dziennie.

Informatorka, podobnie jak Elżbieta M., idealizuje zarówno swój dom rodzinny, jak i rodziców. Świadomość przemijającego czasu, porównanie zachowań dzisiejszych rodziców do postępowania jej matki i ojca - prostych ludzi ze wsi, wychowujących dzieci bez znajomości żadnych „naukowych” zasad tego trudnego procesu, wywołuje refleksję: „Ja im mam więcej lat, tym ich więcej cenię” (AIEIAK 11036, s. 2).

Wedle zebranych opowieści nauczycieli z rodzin chłopskich ich praca była rodzajem powołania, z którym łączyło się poczucie służby na rzecz społeczeństwa, chęć przekazywania pozytywnych wzorców młodzieży i wychowywanie jej w duchu patriotycznym. Wraz z postrzeganiem pracy nauczyciela jako formy pozytywistycznych działań u podstaw, mamy do czynienia z deklarowanym zamiłowaniem do zawodu i dumą z bycia nauczycielem. Zdobyte z trudem wykształcenie, dzięki wsparciu rodziny oraz możliwościom nauki, danym przez władze 
dzieciom z niższych warstw socjalnych, jest dla tych informatorów wartością, pozwalającą na pełnienie ważnej roli społecznej. W swych narracjach mówią o dumie odczuwanej z wykonywanego zawodu, możliwości dzielenia się posiadaną wiedzą z uczniami, ale i pomocy potrzebującej młodzieży w zwykłych życiowych problemach. Praca nauczyciela to dla informatorów coś więcej niż siedzenie na lekcjach w szkole kilka godzin i realizowanie programu nauczania. Wedle ich narracji, okazywane uczniom zainteresowanie, chęć niesienia pomocy i podejmowane próby zrozumienia ich problemów, wykraczały poza instytucjonalną, bezosobową funkcję szkolno-oświatową. Sądzę, że informatorzy, pochodzący ze wsi i rodzin robotniczych, doskonale wpisują się w kategorię osobowości człowieka pracy Floriana Znanieckiego. Zaznali biedy, a bytowe warunki ich dzieciństwa były bardzo trudne. Pozostawali pod wpływem dorosłych ze swojego kręgu rodzinnego, od których uczyli się ról związanych z wykonywaną pracą. W dzieciństwie pozostawali daleko od wpływu kręgów zabawy i wychowawczych. Pracowali od najmłodszych lat, pomagając rodzicom w domu, w polu, zajmując się rodzeństwem. Nie mieli nie tylko zabawek, ale nawet wszystkich potrzebnych ubrań. Cenili i cenią zarówno pracę, jak i naukę (traktując ją jako formę pracy), pozwalającą na zdobycie wykształcenia i awans społeczny. Ich stosunek do wykonywanego zawodu nauczyciela był i pozostał zdominowany przez poczucie obowiązku i użyteczności pracy, którą każdy powinien wykonywać, pozostając posłusznym autorytetom wyznaczającym cel i rodzaj pracy, a stojącym wyżej w hierarchii społecznej. Taki jest rodzaj etyki i swoistej filozofii społecznej, jaka pozostaje ich udziałem. Zasady wykonywania pracy również są ściśle oparte na hierarchii i relacji przełożony - podwładny, które wyznaczają rodzaj pracy i sposoby jej wykonania: „człowiek pracy od dzieciństwa uczy się patrzeć na swe zadanie obiektywnie, jako zależne od swego stanowiska w kręgu pracy. Nie o to chodzi, aby działać twórczo, lecz aby działać ku zadowoleniu przełożonych (...)”25. Nauczyciele jako ludzie pracy wypełniają nakazy innych, stojących wyżej w hierarchii kręgu oraz rozporządzają cudzą pracą, tych stojących niżej w porządku instytucji szkolno-oświatowej. Takiego sposobu wykonywania pracy nauczyli się już w dzieciństwie.

Znaniecki zwraca uwagę na monotonię wciąż powtarzających się czynności w pracujących kręgach rodzinnych, zwłaszcza na wsi. Takim rodzajem kręgu ludzi pracy jest wiejska rodzina, pośród której dorastali moi informatorzy: „znaczną jednostajność znajdujemy w kręgach rodzinnych rolniczo-hodowlanych, gdzie jednostki obojga płci od wczesnych lat uczestniczą w paszeniu i karmieniu zwierząt, uprawie ogrodu i roli, zbieraniu i przetwarzaniu produktów. (...) starsze środowisko uczy młodego osobnika żyć nie tyle przez przygotowywanie go do przyszłych ról społecznych, ile przez zmuszanie go do teraźniejszego odgrywania roli pracownika pomagającego starszym pracownikom. Odmienny, specyficznie wychowawczy wpływ kręgów szkolnych jest przy tym neutralizowany przez bezustanną styczność z pracującym środowiskiem nawet wtedy, gdy młodociany osobnik sam nie pracuje; dziecko z warstwy pracującej zbyt głęboko przyswaja sobie,

25 F. Znaniecki, Ludzie teraźniejsi a cywilizacja przyszłości, Warszawa 2001, s. 187. 
niemal od niemowlęctwa, postawy życiowe otaczających go ludzi pracy, aby w okresie przerywanego pobytu w szkole mogło rozwinąć w sobie dążności, cechujące jednostki, które nie tylko od niemowlęctwa są przedmiotem ciągłych zainteresowań wychowawczych, ale których otoczenie składa się przeważnie z ludzi dobrze wychowanych"26. Nauka w szkole jest dodatkiem do ciężkiej pracy, jaką muszą wykonywać przyszli nauczyciele jako dzieci na wsi, w swoim rodzinnym domu. Jeśli jednak dziecko wykazywało się uzdolnieniami, rodzice starali się pomóc mu w zdobywaniu dalszego wykształcenia i zapewnić awans w hierarchii społecznej. Wedle relacji nauczycieli pochodzących $\mathrm{z}$ chłopskich rodzin, w swoim rodzinnym środowisku spotykali się oni ze zrozumieniem swych aspiracji i chęci dalszego kształcenia. W przypadku rodzin wielodzietnych, wyjście na świat ludzi dobrze wychowanych było możliwe tylko dla najzdolniejszych, reszta dzieci pozostawała w kręgu ludzi pracy. Najbardziej wyraźnie mówi o tym cytowana wcześniej narracja Elżbiety M. (wywiad AIEIAK 10757), opowiadająca o trudnym dzieciństwie na wsi, koniecznych wyrzeczeniach i wysiłku, jaki musiała włożyć w zdobycie wykształcenia.

Henryka D., również pochodząca z wielodzietnej rodziny chłopskiej, nauczycielka języka rosyjskiego w Wiśniowej Górze i Andrespolu, mówi wręcz o miłości zarówno do wykonywanego zawodu, jak i dzieci, które traktowała jak własne. Choć jest już emerytowanym nauczycielem, wciąż spotyka się ze swoimi wychowankami, którzy ją pamiętają i szanują. Ciepłe wspomnienia o szkole i wyrazy okazywanej przez uczniów nawet po latach sympatii, są dla nauczyciela największą nagrodą. Informatorka mówi o sobie, jako o nauczycielu w czasie teraźniejszym, nie przeszłym, wciąż identyfikując się z wykonywaną niegdyś pracą. Bez pracy nie potrafiłaby żyć. Bycie nauczycielem to po prostu nieodłączna i trwała część jej tożsamości, a praca z dziećmi to najlepszy z możliwych zawodów: „Bo już od dzieciństwa kochałam ten zawód. Jak byłam dzieckiem to szkołę robiłam cały czas. Z powołania jestem nauczycielką. Z powołania. Po prostu lubiłam uczyć cudze dzieci. No i pamiętam, kiedyś pani zostawiła mnie na lekcji. Do podstawówki chodziliśmy i mówi: »Heniu, proszę, prowadź tę lekcję«. (...) Byłam bardzo ważna, że ja uczę dzieci. Z powołania zostałam. Kochałam bardzo młodzież. Nikt chyba nie narzeka w Wiśniowej Górze, że byłam niedobra” (AIEIAK 11038, s. 10).

Maria, nauczycielka języka polskiego, urodzona w 1946 roku, w swej wypowiedzi podkreśla rozumienie pracy nauczyciela jako służby społeczeństwu i wyznawanym wartościom. Nauczycielka pochodzi z rodziny robotniczej (lecz jej matka pochodziła ze wsi położonej na Kresach Wschodnich), gdzie wykształcenie było rozumiane jako szansa na awans społeczny i uniknięcie ciężkiej, fizycznej pracy, będącej udziałem jej obojga rodziców: „Idealizm. Platońskie: piękno, dobro, miłość. Chrześcijańskie: prawda was wyzwoli. Literatura. Program i nowele pozytywistyczne. Żeromski »Siłaczka« i »Przedwiośnie«. Stąd moja pierwsza praca na wsi w szkole podstawowej. Potrzeba głębszego celu i sensu życia. Pragnienie dzielenia się z innymi, z młodzieżą i dziećmi, posiadaną

26 Tamże, s. 175-176. 
wiedzą” (AIEIAK 11046, s. 12). Po ukończeniu Studium Nauczycielskiego informatorka pracowała przez rok w małej wiejskiej szkole. Mówi o tym, jak o formie spłacania długu społeczeństwu za daną możliwość awansu społecznego. Później zdecydowała się na dalsze studia dzienne, na dwóch kierunkach. Dzięki otrzymywanemu stypendium i wykorzystanej szansie, danej przez władze komunistyczne dzieciom z rodzin robotniczych i chłopskich, jak też własnej pracy, udało jej się zrealizować swoje marzenie o wykonywaniu zawodu nauczyciela.

Maria, opowiadając o swoim dzieciństwie, spędzanym w kręgu robotniczym, który Florian Znaniecki nazywa „beznadziejnym proletariatem”, mówi o braku nadziei, panującym wśród robotników zapijających alkoholem swój marny los, bez szans na zmiany. Jedynym sposobem na wyrwanie się z tego rodzaju kręgu ludzi pracy jest wykształcenie. To ono jest przez dzieci z wielodzietnych rodzin robotniczych traktowane jako wartość, ważniejsza może niż sama praca. Narracja nauczycielki języka polskiego o powojennym życiu w robotniczej familii jest $\mathrm{w}$ wielu miejscach zgodna $\mathrm{z}$ opisem tego rodzaju proletariackiego kręgu ludzi pracy w dziele Floriana Znanieckiego ${ }^{27}$.

Praca nauczyciela, wybrana przez informatorów, często jest przez nich wykonywana tuż po ukończeniu liceum lub studium pedagogicznego. Dalsze wykształcenie zdobywają, łącząc obowiązki pracy zawodowej ze studiami wieczorowymi lub zaocznymi. Jako ludzie pracy nie wyobrażają sobie próżnowania.

Marianna Z., nauczycielka matematyki, urodzona w 1938 roku, jak wielu innych informatorów, ukończyła najpierw liceum pedagogiczne i pracując zawodowo, studiowała matematykę: „Studiowałam zaocznie, najpierw w Studium Nauczycielskim, a potem wieczorowo. Po zajęciach swoich w szkole jechałam od razu do Łodzi, bo to na UŁ były zajęcia. To wracałam o dziesiątej albo jedenastej do domu. I tak trzy albo cztery dni w tygodniu, przez cztery lata. Także było co robić. No, ale chciałam bardzo ukończyć studia, bo wiedziałam, że jeśli nie skończę wyższych studiów, to mi pozostaną te klasy młodsze do uczenia. A mi bardziej odpowiadały klasy starsze. I bałam się tego, że będę tak troszkę na marginesie, jak nie ukończę studiów. A chciałam być zawsze w czołówce, a nie na końcu” (AIEIAK 12188, s. 5). Jako chłopskie dziecko informatorka wiedziała, że musi być najlepsza, aby udowodnić innym nauczycielom ze szkoły, w której pracowała, że nie jest gorsza od nich. Informatorka pochodzi z wielodzietnej rodziny chłopskiej, na tyle zamożnej, że uznano ją w czasach stalinowskich za dziecko kułaka, które nie powinno się kształcić: „I mój tata musiał pójść do pracy do Warszawy, i zastosować taki wybieg, żebym ja mogła pójść do szkoły i się uczyć. Bo to były takie czasy, że właśnie dzieci kułaków nie powinny się uczyć, tylko dzieci robotnicze i chłopskie” (AIEIAK 12188, s. 1). Podjęciu decyzji o wyborze wymarzonego zawodu nauczyciela towarzyszyło wpojone przez rodziców przekonanie, że wykształcenie jest ważną wartością, dzięki której dziecko ze wsi może wspiąć się wyżej w hierarchii struktury społecznej, a taką szansę należy wykorzystać.

$27 \quad$ Zob.: F. Znaniecki, dz. cyt., s. 215-224. 
Nauczyciele będący inteligencją z awansu w pierwszym pokoleniu, podkreślają, że stał się on możliwy dla dzieci z rodzin chłopskich i robotniczych dzięki ustrojowi socjalistycznemu. Wspomnienia nauczycieli o: sprawowanej przez socjalistyczne państwo opiece socjalnej nad uczniami i studentami, bezpłatnych studiach i pieniądzach płaconych za dobrą naukę, stypendiach dla dzieci z ubogich rodzin, służą jako kolejne argumenty przemawiające za pozytywną oceną Polski Ludowej oraz wyboru drogi życiowej i kariery zawodowej.

Wydaje się, że o ile w osobowościach moich informatorów pozostały pewne elementy tradycyjnego chłopskiego etosu, przekazane przez rodziców, to dotyczą one zwłaszcza pracy jako niezbywalnej wartości, rozumianej jako nakaz moralny, którym powinien kierować się każdy człowiek. Dla nauczycieli, których fragmenty narracji cytowałem, nauka w szkole i na studiach, była również formą pracy. Już nie fizycznej, jak w chłopskim świecie, ale równie ważnej i tak samo rzetelnie wykonywanej dla dobra wspólnoty. Już nie tej w wąskim, rodzinnym rozumieniu, ale szerszej - społeczeństwa. Niekiedy ich narracje (i to nie tylko polonistów) zawierają w sobie toposy wręcz żywcem przeniesione z literatury pozytywistycznej. I tutaj także mamy do czynienia z rozumieniem pracy jako służby społeczeństwu i dobru powszechnemu. Praca miałaby - wedle nauczycieli (i polskiego pozytywizmu) - stanowić o moralnym ładzie świata oraz decydować o społecznej przydatności jednostki. Wreszcie dzięki pracy/nauce moi rozmówcy mogli wydźwignąć się z biedy, dokonać prawdziwego społecznego awansu. To nie była jedynie zasługa państwa - Polski Ludowej - ale ich wysiłku, wyrzeczeń i ciężkiej pracy, również ich rodziców. Państwo dało im szansę, z której skorzystali. Niektórzy z nich starali się odwdzięczyć społeczeństwu i socjalistycznemu państwu za daną możliwość awansu, wracając jako nauczyciele na wieś. Te decyzje przypominały nieco pozytywistyczną motywację pracy u podstaw.

Wedle cytowanych informatorów, zasadę autoteliczności pracy powinien respektować zwłaszcza nauczyciel, jako osoba kształtująca postawy młodzieży i ją wychowująca. Nauczyciele pochodzący z rodzin wiejskich we fragmentach wywiadów podkreślają, że taką zasadę - poszanowania pracy i konieczności jej wykonywania przez każdego człowieka jak najlepiej - starali się przekazać swoim wychowankom. Cechy, o jakich mówią i jakie uznają za pożądane w wykonywanym zawodzie, również przypominają te, obecne w etosie chłopskim: pracowitość, uczciwość, prostolinijność oraz poszanowanie pracującej wspólnoty i rodziny. Próżniactwo, byle jakie wykonywanie obowiązków czy lekceważenie ich, nie mieszczą się w światopoglądzie moich informatorów.

Z pewnością tradycyjny chłopski etos zanikł w wyniku zmian kulturowych, społecznych, ekonomicznych i historycznych. Jednak sądzę, że niektóre z jego elementów przetrwały do dzisiaj, przynajmniej w pokoleniu nauczycieli wywodzących się z rodzin wiejskich, wśród których prowadziłem badania nad pamięcią Polski Ludowej. 


\section{Summary}

Peasant Ethos and Working People. Teachers of Social Advancement about Work in the Studies on the Memory of the People's Republic of Poland 2009-2012

This article is an attempt to find elements of the traditional peasant ethos in narrations of teachers from Łódź. The teachers came from poor peasant families. They got their education thanks to own effort and help of the socialist state. In their relationship to the performed work it is possible to find certain elements of the traditional ethos of the Polish peasant. These element are: diligence, resourcefulness, convincing the performance of work about the need by every man. For them their work is a form of a service for the society.

Key words: autobiographical memory, narration, traditional peasant ethos, teachers from Łódź

Adres mailowy autora: marcin.kepinski@uni.lodz.pl 